\title{
EFEKTIVITAS PENGGUNAAN MEDIA GAMBAR TERHADAP KETERAMPILAN MENULIS CERITA PADA SISWA KELAS V SEKOLAH DASAR
}

\author{
Nursyaida \\ Program Studi Pendidikan Guru Sekolah Dasar, Fakultas Keguruan dan Ilmu Pendidikan, \\ Universitas Muhammadiyah Makassar, Jl. Sultan Alauddin No.259, Makassar, Indonesia \\ 90221
}

\begin{abstract}
This research aims to determine differences in narrative writing skills of students treated learning using media images to the students who are not being treated. The subjects were 26 students $5_{\text {th }}$ grade SD 164 Ara District of Bontobahari Bulukumba. Data collection technique used tests given before and after the study and observation.

Constraints experienced by students in writing the story was stringing words and sentences. Students had difficulties choosing the right words and put them together into sentences that are good and right, thus forming a story. Media images can help inspiring for students. The results showed that the students' narrative writing skills taught using media images is higher than students taught using lecture method. The average score of students in the class treated is 67.41 while the average score of students in the class were not treated was 50.63 .

Students treated learning by using media images were active during the learning process. Many students in the control class who remain silent and confused not knowing what is about to be written.
\end{abstract}

Keywords: narrative writing skills, media images

\begin{abstract}
Abstrak
Penelitian ini bertujuan untuk mengetahui perbedaan keterampilan menulis cerita siswa yang diberi perlakuan pembelajaran menggunakan media gambar dengan siswa yang tidak diberi perlakuan. Subjek penelitian adalah siswa kelas V SD 164 Ara Kecamatan Bontobahari Kabupaten Bulukumba sebanyak 26 orang. Teknik pengumpulan data menggunakan tes yang diberikan sebelum dan setelah pembelajaran serta observasi.

Kendala yang dialami siswa dalam menulis cerita adalah merangkai kata dan kalimat. Siswa sulit memilih kata yang tepat dan merangkainya menjadi kalimat-kalimat yang baik dan tepat, sehingga membentuk suatu cerita. Media gambar dapat membantu menimbulkan inspirasi bagi siswa. Hasil penelitian menunjukkan bahwa keterampilan menulis cerita siswa yang diajar dengan menggunakan media gambar lebih tinggi dibanding siswa yang diajar dengan menggunakan metode ceramah. Skor rata-rata siswa pada kelas yang diberi perlakuan adalah 67,41 sedangkan skor rata-rata siswa pada kelas yang tidak diberi perlakuan adalah 50,63.

Siswa yang diberi perlakuan pembelajaran dengan menggunakan media gambar terlihat aktif selama proses pembelajaran. Berbeda dengan siswa pada kelas yang tidak diperlakuan. Banyak siswa di kelas tersebut yang tinggal diam dan kebingungan tidak mengetahui apa yang hendak ditulis.
\end{abstract}

Kata kunci: keterampilan menulis, media gambar 


\section{Pendahuluan}

Menulis merupakan suatu tuntutan keterampilan yang harus dikuasai oleh manusia sebagai bahasa tulis (Pantow, 2002). Menulis merupakan suatu keterampilan berbahasa yang dipergunakan untuk berkomunikasi secara tidak langsung, tidak secara tatap muka dengan orang lain.

Terdapat empat unsur yang terlibat dalam kegiatan menulis, yaitu penulis sebagai penyampai pesan, pesan atau isi tulisan, saluran atau media berupa tulisan, dan pembaca sebagai penerima pesan.

Proses menulis memiliki lima tahap yakni: (1) tahap pramenulis, (2) tahap drafting, (3) tahap merevisi, (4) tahap mengedit, (5) tahap memublikasikan

(Tompkins, 1994). Menurut Syafi'ie (1993) secara garis besar ada tiga tahap menulis, yaitu persiapan (prewriting), penulisan (composing), dan revisi (revition). Farris (1993) menjelaskan tahap-tahap dalam proses menulis yakni (1) pramenulis, (2) menulis, (3) penulisan kembali, dan (4) penerbitan.

Kemampuan menulis yang dapat dikembangkan ialah kemampuan reproduktif, reseptif-produktif, dan produktif. Kegiatan yang dilakukan terkait kemampuan produktif ialah menyalin teks dari buku atau papan tulis. Kegiatan yang dilakukan dalam mengembangkan kemampuan reseptif-produktif adalah siswa membaca sendiri suatu teks atau mendengar melalui kaset, kemudian siswa memproduksi atau menceritakan isi teks. Kegiatan yang dilakukan dalam pengembangan kemampuan produktif, siswa harus menulis secara bebas berdasarkan tema yang diberikan dengan pertolongan kata kunci. Kegiatan ini melalui tiga tahap yaitu: (1) menulis konsep cerita, (2) menyusun bahasa, dan (3) membuat komposisi yang sesuai (Hariadi, 1997). Siswa dapat berpedoman pada pengalaman, perasaan dan pengetahuan yang dimiliki untuk menghasilkan tulisan dengan mengembangkan kata-kata kunci.

Menulis merupakan suatu kegiatan yang produktif dan ekspresif (Tarigan, 1994). Oleh karena itu, sejak dini pengajaran bahasa selalu harus didasarkan pada keterampilan bahasa dan salah satunya adalah menulis. Menulis permulaan dibinakan pada kelas I dan II di SD sedangkan menulis lanjut dibinakan mulai kelas III sampai VI SD. Tujuan pembelajaran menulis lanjut secara umum adalah untuk membina para siswa untuk mampu mengekspresikan perasaan dan pikirannya ke dalam bahasa tulis.

Berdasarkan hasil wawancara awal dengan guru kelas V SD 164 Ara Kecamatan Bontobahari Kabupaten Bulukumba terungkap bahwa siswa mengalami kendala dalam memilih kata dan kurang mampu merangkai kalimat.

Dalam kegiatan menulis siswa memerlukan suasana dan kondisi yang kondusif. Kondisi konsentrasi yang santai dengan melihat gambar dapat sangat membantu meningkatkan imajinasi siswa. Dari imajinasi itu siswa mampu merangkai kata dan kalimat menjadi suatu cerita.

Langkah-langkah pembelajaran menulis menggunakan media gambar sebagai berikut:

a. Guru menggunakan gambar sesuai pertumbuhan dan perkembangan siswa

b. Guru memasang gambar di depan kelas untuk diperlihatkan kepada siswa

c. Guru menerangkan pembelajaran dengan menggunakan gambar

d. Guru mengarahkan perhatian siswa pada suatu gambar sambil mengajukan pertanyaan kepada siswa secara satu persatu

e. Guru memberikan tugas menulis pada siswa

Berdasarkan pemikiran tersebut, dilakukan penelitian untuk menyelidiki keefektifan penggunaan media gambar dalam mengembangkan keterampilan 
menulis cerita siswa kelas V SD 164 Ara Kecamatan Bontobahari Kabupaten Bulukumba.

\section{Metode Penelitian}

Penelitian ini merupakn penelitian eksperimen semu dengan menggunakan eksperiment-control pre test posttest group design.

Penelitian dilakukan di SD 164 Ara Kecamatan Bontobahari Kabupaten Bulukumba dengan melibatkan dua kelompok, yaitu kelompok eksperimen dan kelompok kontrol.

Kelompok eksperimen yaitu kelas VA sebanyak 36 siswa diberi perlakuan pembelajaran dengan menggunakan media gambar. Kelompok kontrol, yaitu kelas VB sebanyak 32 siswa diajar sebagaimana biasa menggunakan metode ceramah.

Sebelum pelaksanakan pembelajaran, kedua kelompok diberi tes keterampilan menulis cerita untuk memastikan bahwa kedua kelompok itu homogen. Setelah pelaksanaan pembelajaran, kedua kelompok kembali diberi tes keterampilan menulis cerita.

Aspek penilaian Nurgiyantoro (2005) digunakan untuk melakukan penilaian karangan siswa.

\section{Hasil Dan Pembahasan}

Dua kelompok dalam penelitian ini diberi perlakuan berbeda. Kelompok eksperimen diberi perlakuan pembelajaran dengan menggunakan media gambar, sedangkan kelompok kontrol diajar dengan menggunakan metode ceramah. Kegiatan pembelajaran dilakukan selama 4 pertemuan. Sebelum dan sesudah rangkaian 4 pertemuan tersebut, siswa dari kedua kelompok diberi tes keterampilan menulis.

Hasil tes awal menunjukkan kemampuan kedua kelompok berbeda tapi tidak cukup signifikan. Hasil tes akhir kedua kelompok menunjukkan perbedaan, skor rata-rata kelompok eksperimen adalah 67,41, sedangkan kelompok kontrol adalah 50,63. Skor tertinggi yang diraih kelompok eksperimen adalah 100 (skor ideal), sedangkan skor tertinggi kelompok kontrol hanya mencapai 82.

Berdasarkan aspek ketuntasan, sebanyak 23 siswa kelas kontrol atau $71,87 \%$ belum mencapai ketuntasan. Hanya 9 siswa atau 28,13\% yang mencapai ketuntasan. Hal berbeda diperoleh pada kelas eksperimen. Sebanyak 23 siswa atau 63,89\% mencapai ketuntasan belajar dan 13 siswa atau 36,11\% belum mencapai ketuntasan. Meskipun masih banyak siswa yang belum tuntas di kelas eksperimen dan nilai rata-rata hanya sedikit diatas nilai standar 65 , tetapi kemampuan yang ditunjukkan kelas eksperimen sudah cukup baik dibanding kelas kontrol.

Berikut disajikan distribusi frekuensi hasil tes keterampilan menulis kelas kontrol.

Tabel 1. Hasil Tes Keterampilan Menulis Kelas Kontrol

\begin{tabular}{|c|c|c|c|}
\hline Skor & Kategori & Frek & Persentase \\
\hline $0-54$ & $\begin{array}{l}\text { Sangat } \\
\text { Rendah }\end{array}$ & 19 & 59,38 \\
\hline $55-64$ & Rendah & 4 & 12,50 \\
\hline $65-79$ & Sedang & 6 & 18,75 \\
\hline $80-89$ & Tinggi & 3 & 9,37 \\
\hline $90-100$ & $\begin{array}{c}\text { Sangat } \\
\text { tinggi }\end{array}$ & 0 & 0 \\
\hline \multicolumn{2}{|c|}{ Jumlah } & 32 & 100 \\
\hline
\end{tabular}



eksperimen.

Berikut disajikan distribusi frekuensi hasil tes keterampilan menulis kelas

Tabel 2. Hasil Tes Keterampilan Menulis Kelas Eksperimen

\begin{tabular}{|c|c|c|c|}
\hline Skor & Kategori & Frek & Persentase \\
\hline $0-54$ & $\begin{array}{l}\text { Sangat } \\
\text { Rendah }\end{array}$ & 9 & 25,00 \\
\hline $55-64$ & Rendah & 4 & 11,11 \\
\hline $65-79$ & Sedang & 12 & 33,33 \\
\hline $80-89$ & Tinggi & 7 & 19,45 \\
\hline $90-100$ & $\begin{array}{c}\text { Sangat } \\
\text { tinggi }\end{array}$ & 4 & 11,11 \\
\hline \multicolumn{2}{|c|}{ Jumlah } & 36 & 100 \\
\hline
\end{tabular}

Perbandingan deskriptif hasil tes kelompok eksperimen dan kelompok kontrol disajikan dalam tabel berikut.

Tabel 3. Perbandingan Hasil Tes Kedua Kelompok

\begin{tabular}{lrr}
\hline \multirow{2}{*}{ Statistik } & \multicolumn{2}{c}{ Nilai } \\
\cline { 2 - 3 } & Eksperimen & Kontrol \\
\hline Ukuran sampel & 36 & 32 \\
\hline Skor tertinggi & 100 & 82 \\
\hline Skor terendah & 10 & 10 \\
\hline Skor ideal & 100 & 100 \\
\hline Rentang skor & 90 & 72 \\
\hline Skor rata-rata & 67,41 & 50,63 \\
\hline Standar deviasi & 20,86 & 19,25 \\
\hline
\end{tabular}

Selain membandingkan hasil tes dari kedua kelompok, peneliti juga mengamati aktivitas belajar kelompok eksperimen untuk melihat efektivitas pembelajaran yang dilakukan.

Pengamatan dilakukan terhadap aspek (1) kedisplinan siswa mengikuti proses pembelajaran, (2) siswa yang memperhatikan penjelasan guru, (3) siswa yang aktif bertanya, (4) siswa yang antusias menggunakan media gambar, (5) siswa yang menyelesaikan tugas tepat waktu, (6) siswa yang masih memerlukan bimbingan dalam menulis cerita, dan (7) siswa yang melakukan aktivitas yang tidak relevan dengan kegiatan pembelajaran.

Hasil pengamatan pada kelas eksperimen menunjukkan persentase ratarata dari empat pertemuan untuk aspek kedisplinan siswa mengikuti proses pembelajaran sebesar $75,05 \%$. Persentase rata-rata aspek siswa yang memperhatikan penjelasan guru sebesar 77,81\%. Persentase rata-rata aspek siswa yang aktif bertanya selama proses pembelajaran berlangsung sebesar 58,32\%. Persentase rata-rata aspek siswa yang antusias menggunakan media gambar sebesar 77,84\%. Persentase rata-rata aspek siswa yang menyelesaikan tugas tepat waktu sebesar 94,43\%. Persentase rata-rata aspek siswa yang masih memerlukan bimbingan dalam menulis cerita sebesar $27,8 \%$. Persentase rata-rata aspek siswa yang melakukan aktivitas yang tidak relevan dengan kegiatan pembelajaran sebesar $22,21 \%$.

Berdasarkan temuan tersebut terungkap bahwa siswa aktif dan serius mengikuti pembelajaran dengan menggunakan media gambar. Siswa antusias menulis cerita karena mereka menemukan inspirasi dari gambar yang dapat dituangkan dalam ceritanya. Masih ada siswa yang melakukan aktivitas tidak relevan dengan kegiatan pembelajaran seperti mengganggu atau melihat 
pekerjaan temannya, keluar masuk kelas dengan alasan ke kamar kecil, dan sebagainya. Akan tetapi aktivitas itu semakin berkurang selama empat kali pertemuan yang dilakukan. Hal ini juga dikarenakan guru selalu mengingatkan siswa untuk berkonsentrasi agar dapat menyelesaikan tugas dengan baik.

Hal berbeda ditemukan pada kelas kontrol. Siswa lebih banyak diam dan kurang bersemangat, hanya mendengarkan arahan guru. Siswa kesulitan memilih kata dan merangkainya menjadi kalimat-kalimat. Akibatnya, banyak siswa yang tidak dapat menyelesaikan tulisannya dalam batas waktu yang ditentukan.

Selain menginspirasi siswa untuk menulis, media gambar juga menarik sehingga siswa dapat lebih focus pada pembelajaran, tidak merasa jenuh atau bosan belajar. Hanya saja ada beberapa siswa yang terlalu antusias sehingga selalu ingin menceritakan kepada temannya apa idenya dan apa yang sedang ditulisnya atau balik bertanya kepada temannya apa yang sedang ditulis temannya.

\section{Kesimpulan}

Berdasarkan hasil pengamatan dan hasil tes keterampilan menulis cerita, ditemukan bahwa penggunaan media gambar dapat menginspirasi siswa untuk menulis cerita dan menghilangkan kebosanan atau kejenuhan belajar siswa. Penggunaan media ini dapat meningkatkan antusiasme siswa. Hal ini berdampak pada kemampuan siswa menulis cerita dengan baik.

Oleh karena itu, disarankan kepada guru-guru di sekolah dasar untuk membantu siswa dalam meningkatkan keterampilan menulis cerita dengan menggunakan bantuan media gambar.

\section{Daftar Pustaka}

Akhadiah. 1996. Pembinaan Kemampuan Menulis. Jakarta: Erlangga.

Farris, P.J. 1993. Language Arts: A Process Approach. Madison Bbrown \& Benchmark Publishers.

Hariadi \& Zamsani. 1997. Kemampuan Menulis. Jakarta: Bumi Aksara.

Kosasih, R. Angkowo. 2007. Optimalisasi Media Pembelajaran. Jakarta: Grasindo

Nurgiyantoro, Burhan. 2005. Sastra Anak: Pengantar Pemahaman Dunia Anak. Gadjah Mada University Press.

Suparno. 2004. Keterampilan Dasar Menulis. Jakarta. Universitas Terbuka.

Syafi'ie. Imam. 1993. Retorika dalam Menulis dan Prinsip-Prinsip Pengajaran Bahasa dan Satra. Jakarta: Depdikbud

Tarigan, H.G. 1994. Menulis sebagai Suatu Kegiatan yang Produktif dan Ekspresif. Bandung 